\title{
Self Regulation Santri Penghafal Alquran Usia Sekolah Dasar
}

\author{
Kharis Sulaiman Hasri ${ }^{1}$, Suyadi ${ }^{2} *$ \\ ${ }^{1}$ Pendidikan Guru Madrasah Ibtidaiyah, Universitas Islam Negeri Sunan Kalijaga, Yogyakarta, Indonesia \\ ${ }^{2}$ Pendidikan Islam Anak Usia Dini, Universitas Islam Negeri Sunan Kalijaga, Yogyakarta, Indonesia \\ *e-mail: suyadi@uin-suka.ac.id
}

\begin{tabular}{|c|c|}
\hline Abstract / Abstrak & Keywords / Kata kunci \\
\hline $\begin{array}{l}\text { The purpose of this study is to explore self-regulation of Alquran memorizers in } \\
\text { elementary school age. This study used a qualitative method with a } \\
\text { phenomenological approach. The participants were collected using purposive } \\
\text { sampling, which consisted of six students, five parents, and one teacher. The data } \\
\text { collection instrument used semi-structured in-depth interviews and observation } \\
\text { guidelines. The data were analyzed using the theory of Miles and Huberman with } \\
\text { the stages of reduction, presentation, and conclusion. The self-regulation of } \\
\text { elementary school students who memorize the Alquran is still guided by their } \\
\text { parents both in setting goals, motivation and aspects of affection. In achieving } \\
\text { goals, it is also influenced by the motivational aspects which are dominated by } \\
\text { transcendental motivation. Meanwhile, the affection aspect occurs in a transition } \\
\text { process from extrinsic motivation to intrinsic motivation. }\end{array}$ & $\begin{array}{l}\text { Self Regulation; } \\
\text { Alquran memorization; } \\
\text { Elementary School Age }\end{array}$ \\
\hline $\begin{array}{l}\text { Tujuan penelitian ini untuk mengetahui regulasi diri penghafal Alquran usia } \\
\text { sekolah dasar. Penelitian ini menggunakan metode kualitatif dengan pendekatan } \\
\text { fenomenologi. Informan terdiri dari enam santri, lima orang tua, dan satu orang } \\
\text { guru. Pengambilan informan menggunakan purposive sampling. Instrumen } \\
\text { pengambilan data menggunakan wawancara mendalam semi terstruktur dan } \\
\text { pedoman observasi. Data dianalisis menggunakan teori Miles dan Huberman } \\
\text { dengan tahapan reduksi, penyajian, dan penarikan simpulan. Hasil menunjukkan } \\
\text { regulasi diri santri penghafal Alquran usia sekolah dasar sebagian besar masih } \\
\text { dibimbing oleh orang tua baik dalam penetapan tujuan, motivasi dan aspek afeksi. } \\
\text { Dalam pencapaian tujuan, juga dipengaruhi aspek motivasional yang didominasi } \\
\text { oleh motivasi transendental. Sedangkan aspek afeksi terjadi proses peralihan } \\
\text { motivasi ekstrinsik menuju motivasi intrinsik. }\end{array}$ & $\begin{array}{l}\text { Regulasi Diri; } \\
\text { Penghafal Alquran; } \\
\text { Usia Sekolah Dasar }\end{array}$ \\
\hline
\end{tabular}

\section{Pendahuluan}

Tidak dapat dipungkiri bahwa sebagian kegagalan yang dialami santri dalam menghafal Alquran disebabkan oleh ketidakmampuan dalam meregulasi diri. Regulasi diri merupakan kemampuan seseorang untuk mengatur, mengontrol, mengevaluasi serta memilih dan menetapkan reaksi diri terhadap suatu capaian (Mu'min, 2016). Sebagian santri mampu mempertahankan hafalan yang telah dikuasai, sedangkan yang lain belum berhasil mempertahankannya. Artinya, sebagian santri belum mampu meregulasi diri lebih baik lagi. Seseorang yang tidak mampu menetapkan tujuan, memotivasi diri, menjaga afeksi (perasaan) dan melakukan evaluasi terhadap diri dapat menyebabkan dirinya melakukan hal yang tidak diinginkan oleh dirinya sendiri maupun orang lain. Bahkan, DeWall dkk. (2007) menerangkan, "regulasi diri yang kurang efektif dapat memberikan dampak perilaku yang agresif".

Sejauh ini penelitian yang dilakukan tentang regulasi diri lebih berfokus pada usia remaja atau dewasa (Susanti, 2015; Rachmah, 2015; Mu'min, 2016; Husna dkk., 2014; Marza, 2017; Lukmawati dkk., 2017), sedangkan regulasi diri penghafal Alquran anak usia sekolah dasar cenderung diabaikan. Memang penelitian tentang regulasi diri pada anak telah dilakukan Colman dkk. (2006) yang mengkorelasikan antara praktik pengasuhan anak usia 4-5 tahun terhadap pengelolaan diri mereka ketika berusia 8-9 tahun, tentang peran reinforcement dalam kemampuan regulasi diri 
siswa SD (Sulistyaningsih \& Cahyani, 2011), berkenaan perbedaan regulasi diri dalam belajar pada siswa akselerasi dan reguler (Adipura dkk., 2014), dan tentang perbedaan regulasi diri berdasarkan jenis kelamin (Ruminta dkk., 2017). Di sisi lainnya, objek penelitian tentang regulasi diri telah menjelaskan beberapa penemuan diantaranya bahwa regulasi diri sangat berkaitan erat dengan fungsi adaptif (Buckner dkk., 2009), regulasi diri memiliki pengaruh positif dan signifikan terhadap hasil belajar (Friskilia \& Winata, 2018), efektivitas konseling realitas terhadap regulasi diri (Susanti, 2015), regulasi diri belajar mahasiswa yang memiliki peran banyak (Rachmah, 2015) dan regulasi mahasiswa yang bekerja dengan prestasi yang baik (Mu'min, 2016). Penelitian tersebut memiliki perbedaan dengan penelitian yang diangkat peneliti, yaitu menekankan pada dinamika regulasi diri penghafal Alquran, sehingga menambah khazanah keilmuan tentang regulasi diri.

Penelitian ini mengungkapkan serta melengkapi kajian terdahulu dari sisi self regulation pada anak penghafal Alquran usia sekolah dasar. Kajian ini penting dilakukan karena menghafal Alquran pada waktu kecil memiliki efek yang lebih baik jika dibandingkan pada usia dewasa hingga usia lanjut (Rifa'i, 2017). Dari penelitian ini diharapkan dapat memberikan perspektif baru tentang regulasi diri pada usia anak.

Self regulation atau regulasi diri berasal dari bahasa Inggris yang terdiri dari dua kata, yaitu self yang berarti diri, dan regulation yang berarti terkelola atau pengelolaan (Ghufron \& Risnawita, 2010: 57). Pengelolaan diri menurut Diaz dkk. dalam Anindyta dan Suwarjo (2014) adalah kemampuan seseorang untuk merencanakan, memandu, serta mengawasi aktivitasnya sendiri yang bersifat dinamis sesuai dengan perubahan kondisi (Anindyta \& Suwarjo, 2014). Zimmerman (dalam Minauli \& Butarbutar, 2011) menyebutkan bahwa regulasi diri dapat dipahami melalui keaktifan berpartisipasi secara metakognisi, motivasional, maupun perilaku dalam proses belajar. Aisyah (dalam Mu'min, 2016) mengemukakan bahwa regulasi diri merupakan kemampuan seseorang untuk mengatur, mengontrol, mengevaluasi serta memilih dan menetapkan reaksi diri terhadap suatu capaian.

Zimmerman menjelaskan tahapan-tahapan regulasi diri terdiri dari: 1) Metakognitif, yaitu pemahaman dan kesadaran dalam proses kognitif atau pikiran tentang berpikir, 2) Motivasi, fungsi dari kebutuhan dasar dalam mengontrol yang berkaitan dengan kemampuan individu, 3) Perilaku, usaha individu dalam mengatur, menyeleksi, serta memanfaatkan/ menciptakan lingkungan yang mendukung aktivitasnya (Zimmerman, 1989). Sedangkan menurut Bandura (2010), proses regulasi diri terdiri dari tiga tahapan, yaitu: 1) pegamatan diri, yakni seseorang memperhatikan diri dan perilakunya kemudian secara terus-menerus mengawasinya, 2) penilaian, yakni seseorang menilai diri dan perilaku dengan cara membandingkannya terhadap standar ukuran yang ada, dan 3) respons diri, yakni memberikan respons seperti memberi imbalan jika diri dan perilaku tersebut sesuai dengan standar. Jika sebaliknya, maka seseorang dapat mengganjar dirinya dengan respons diri. Sementara itu Chairani dan Subandi (2010) menjelaskan bahwa regulasi diri seseorang dapat dilihat dari tiga indikator, yaitu: 1) penetapan, pemeliharaan dan pencapaian tujuan, 2) motivasi, dan 3) afeksi.

Zimmerman, berpendapat "jika seseorang kehilangan cara atau strategi dalam meregulasi diri, maka akan mengakibatkan proses mencapai tujuan yang lebih buruk" (Minauli \& Butarbutar, 2011). Sebaliknya, seseorang yang memiliki regulasi diri baik maka ia memiliki indeks fungsi adaptif yang jauh lebih baik di seluruh ukuran kompetensi sosial, prestasi akademik, nilai, kontrol perilaku bermasalah dan depresi (Buckner dkk., 2009). Selain itu Friskilia dan Winata (2018) mengemukakan bahwa "regulasi diri memiliki korelasi yang positif dan signifikan terhadap prestasi belajar". Perlu disadari juga bahwa memang regulasi diri seseorang dipengaruhi oleh banyak faktor, diantaranya: training atau latihan mandiri (Miksza, 2011), pola asuh pada usia dini 
(Colman dkk., 2006), fungsi keluarga serta daya juang (Herawaty \& Wulan, 2013), konseling realitas (Susanti, 2015), situasi dan karakteristik tiap individu yang bersangkutan serta dukungan sosial (Rachmah, 2015), dan strategi pembelajaran (Anindyta \& Suwarjo, 2014).

Penghafal Alquran biasa disebut dengan istilah hăfiz (bagi laki-laki) dan hăfizah (bagi perempuan). Kata hăfiz berasal dari kata hafiza yang berarti menjaga (jangan sampai rusak), memelihara atau melindungi (Munawwir, 1997: 279). Shihab (dalam Hidayah, 2016) menerangkan kata hăfiz berarti memelihara dan mengawasi, yang darinya lahir makna menghafal. Istilah lain yang digunakan untuk menunjuk "penghafal" yaitu hāmil bentuk jamaknya hamalah (penghafal/ pembawa) (Atabik, 2014). Menurut Chairani dan Subandi (2010) istilah tersebut terambil dari kata haffaza yang menunjukkan arti menghafal. Sedangkan kata menghafal menurut Bahri dalam Marza (2017) dijelaskan bahwa menghafal adalah aktivitas internalisasi materi verbal ke dalam ingatan, sehingga nantinya dapat diingat kembali ke alam sadar (Marza, 2017). Menghafal Alquran merupakan salah satu bentuk pemeliharaan dan penjagaan Alquran sehingga wahyu Allah dapat terpelihara serta terjaga dari perubahan dan penggantian, baik huruf maupun susunan kata-katanya sepanjang masa (Akbar \& Ismail, 2016; al Maududi dkk., 2014). Fauziyah dkk. (2018) mengungkapkan bahwa "proses mengingat, menghafal serta memahami kalimat-kalimat Alquran menjadi kunci utama agar seseorang dapat mengamalkan pesan Allah Swt. di dalamnya”.

Menurut Chairani dan Subandi (2010) penghafal Alquran terikat dengan beberapa kaidah penting, yaitu: 1) Ikhlas, seseorang menghafal Alquran dengan niat dan tujuan semata-mata untuk beribadah serta mendekatkan diri kepada Allah Swt., 2) Memperbaiki bacaan, hal ini karena bacaan Alquran berbeda dengan bacaan lainnya walaupun berbahasa Arab, 3) Menentukan presentasi hafalan setiap hari, 4) Tidak melampaui kurikulum harian, 5) Konsisten dengan satu mushaf, 6) Pemahaman adalah cara menghafal, 7) Memperdengarkan bacaan secara rutin, 8) Mengulangi secara rutin, 9) Menggunakan tahun-tahun atau waktu yang tepat untuk menghafal. Sementara itu, menurut Hidayat (2018), hal penting yang harus dimiliki dan dijalankan seorang penghafal Alquran yaitu: 1) Ikhlas, 2) Serius, 3) Sabar, 4) Yakin, 5) Menghadirkan motivasi, 6) Menjadikan prioritas, 7) Memilih guru, 8) Istiqamah/ konsisten.

Menghafal Alquran dapat dilakukan dengan beberapa metode atau cara. Menurut Ahsin (dalam Qamariah \& Irsyad, 2016: 4245), metode dalam menghafal Alquran diantaranya: 1) Metode Wahdah, yaitu dengan cara membaca satu ayat yang hendak dihafalkan dan diulang sebanyak sepuluh sampai dua puluh kali sampai benar-benar hafal. Setelah hafal ayat pertama, maka dilanjutkan pada ayat berikutnya. 2) Metode Kitäbah, yaitu dengan cara orang tua atau guru menuliskan ayat-ayat yang hendak dihafal oleh anak. Anak membaca ayat yang telah ditulis sampai benar-benar lancar. 3) Metode Simā'i, yaitu dengan cara mendengarkan bacaan ayat-ayat Alquran yang hendak dihafal. Metode ini dapat dilakukan dengan dua cara. Pertama, orang tua atau guru membacakan ayat kepada anak secara berulangulang sampai anak hafal (sesuai kemampuan anak). Kedua, orang tua dapat menggunakan perkembangan teknologi dengan cara merekam bacaan ayat yang akan dihafal dan diperdengarkan kepada anak atau dengan download murattal MP3. 4) Metode Gabungan, metode ini merupakan gabungan dari metode wahdah dan metode kitābah. 5) Metode Jama', metode ini dilakukan dengan cara bersamasama membaca ayat yang akan dihafal yang dipimpin oleh seorang guru.

Rumah Tadabbur Qur'an (RTQ) merupakan salah satu lembaga yang bergerak di bidang pendidikan Alquran yang beriringan dengan lembaga non formal seperti Taman Pendidikan Alquran (TPA/TPQ). RTQ sebagai lembaga pendidikan berusaha untuk memberikan kontribusi peradaban melalui tahfiz dan tadabbur Alquran. Tahfiz dan 
tadabbur dilakukan melalui metode gerak kaisa, yaitu metode untuk menghafal ayat-ayat Alquran yang pada setiap kata dalam ayat Alquran divisualisasikan dengan gerakangerakan tertentu. Gerakan-gerakan tersebut merupakan representasi dari arti/ makna kata ayat. RTQ fleksibel dalam menetapkan target hafalan santri setiap harinya. Artinya santri juga diberi kesempatan untuk menetapkan target hafalannya secara mandiri.

Self regulation sangat penting bagi penghafal Alquran. Hal ini karena seorang penghafal Alquran memiliki kewajiban untuk menjaga hafalannya sebagaimana yang telah ditetapkan, sehingga ia harus mengatur waktu yang dimiliki agar hafalannya dapat terjaga. Selain itu, aspek motivasi dan aspek afeksi merupakan aspek penting dalam regulasi diri penghafal Alquran. Oleh karena itu terdapat tiga hal pokok yang menjadi tujuan penelitian ini, yaitu: bagaimana penetapan dan pencapaian tujuan, bagaimana aspek motivasi dalam regulasi diri, dan bagaimana aspek afeksi regulasi diri penghafal Alquran.

\section{Desain Penelitian}

\section{Metode}

Penelitian ini menggunakan metode kualitatif yang bertujuan untuk melakukan studi secara mendalam tentang self regulation sehingga menghasilkan gambaran yang komprehensif dan holistik atau lengkap (Sugiyono, 2012). Melalui pendekatan kualitatif fenomenologi (Raco, 2010) peneliti berusaha mengungkapkan dan menggali lebih dalam tentang fenomena-fenomena yang terjadi dalam diri penghafal Alquran usia sekolah dasar.

\section{Lokasi dan Subjek Penelitian}

Lokasi penelitian ini bertempat di Rumah Tadabbur Qur'an (RTQ) kota Kendari Provinsi Sulawesi Tenggara. Pemilihan tempat ini didasarkan pada pertimbangan bahwa lembaga RTQ Kendari adalah lembaga yang berkonsentrasi pada pengembangan tahfidz Alquran dan arti/ terjemah ayat (tadabbur) usia dini sampai dengan usia sekolah dasar.
Tabel 1

Informan/ Narasumber Kunci

\begin{tabular}{lccc}
\hline $\begin{array}{c}\text { Nama } \\
\text { Inisial }\end{array}$ & Gender & Usia & $\begin{array}{c}\text { Jumlah } \\
\text { Hafalan }\end{array}$ \\
\hline $\mathrm{NF}$ & $\mathrm{P}$ & 8 tahun & $3 \mathrm{juz}$ \\
$\mathrm{NB}$ & $\mathrm{P}$ & 8 tahun & $3 \mathrm{juz}$ \\
$\mathrm{AN}$ & $\mathrm{P}$ & 7 tahun & $2.5 \mathrm{juz}$ \\
$\mathrm{M}$ & $\mathrm{P}$ & 11 tahun & $1.5 \mathrm{juz}$ \\
$\mathrm{MZ}$ & $\mathrm{L}$ & 10 tahun & $2 \mathrm{juz}$ \\
$\mathrm{ARD}$ & $\mathrm{P}$ & 10 tahun & $2 \mathrm{juz}$ \\
\hline
\end{tabular}

Tabel 2

Informan/ Narasumber Pendukung

\begin{tabular}{lcl}
\hline Nama Inisial & Usia & Keterangan \\
\hline Y & 37 & Orang Tua ARD \\
T & 40 & Orang Tua M \\
EL & 30 & Orang Tua NB \\
FM & 32 & Orang Tua NF dan AN \\
NA & 30 & Orang Tua MZ \\
N & 25 & Guru \\
\hline
\end{tabular}

Informan atau subjek ditentukan berdasarkan karakteristik jumlah hafalan Alquran minimal satu juz. Diperoleh sebanyak enam orang santri yang memenuhi kriteria tersebut, yang mana informan kunci ini rata-rata memiliki hafalan Alquran sebanyak dua sampai dengan empat juz. Informan pendukung terdiri dari lima orang tua/ wali santri dan satu guru tahfidz (lihat tabel 1 dan tabel 2).

\section{Teknik Pengumpulan Data}

Teknik pengumpulan data dilakukan dengan tiga cara yaitu: observasi, wawancara mendalam, dan dokumentasi. Observasi dilakukan dengan dua cara, yaitu pertama observasi partisipasi pasif, dengan cara peneliti mengamati aktivitas subjek tanpa ikut terlibat dalam kegiatan atau aktivitas tersebut. Kedua, observasi tersamar, yakni pengamatan yang dilakukan peneliti dengan tanpa diketahui oleh subjek bahwa peneliti sedang mengamatinya. Selain itu, peneliti juga melakukan wawancara mendalam semi terstruktur kepada setiap informan agar mendapatkan informasi yang sesuai dengan fokus penelitian. Pertanyaan penelitian disusun berdasarkan tiga aspek regulasi diri. Contoh pertanyaan diantaranya: 
"Mengapa Adik menghafal Alquran?", "Bagaimana cara Adik menghafal Alquran?", "Dalam satu hari berapa banyak Adik menambah hafalan Alquran?”. Wawancara dilakukan sebanyak dua kali. Sementara itu, teknik dokumentasi dilakukan terhadap dokumen-dokumen seperti sertifikat hafalan dan buku kontrol hafalan santri.

Analisis data dilakukan dengan tiga tahapan, menggunakan teori Miles Huberman yaitu: pertama, reduksi data, peneliti pada tahap ini akan memilih data-data yang penting sesuai dengan fokus penelitian, kemudian melakukan kategorisasi, dan membuang data yang tidak digunakan atau tidak sesuai dengan fokus penelitian. Kedua, penyajian data, menyajikan data untuk melihat gambaran secara holistik atau bagian-bagian tertentu dari penelitian. Peneliti akan menyajikan data dalam bentuk teks yang bersifat naratif. Selain itu, peneliti akan mengurutkan data yang diperoleh sehingga terlihat gambaran secara komprehensif dan menyeluruh. Ketiga, tahap penarikan kesimpulan berdasarkan temuan kemudian melakukan verifikasi data. Peneliti akan membuat kesimpulan-kesimpulan sementara kemudian melakukan verifikasi data setelah pengambilan data di lapangan. Ketiga tahapan ini berlangsung terus-menerus sampai data yang diperoleh benar-benar valid (Prastowo, 2019). Sementara itu, untuk mengecek kevalidan data, peneliti melakukan triangulasi sumber yang dilakukan kepada guru dan orang tua santri, triangulasi teknik dilakukan dengan wawancara, observasi dan dokumentasi, serta triangulasi waktu dilakukan pada waktu sore dan malam.

\section{Hasil}

Regulasi diri yang terjadi dalam diri santri penghafal Alquran usia sekolah dasar berdasarkan tiga tujuan penelitian, yang diambil dari hasil wawancara dan observasi.

\section{Memiliki Target Hafal 30 Juz Alquran}

Hampir keseluruhan informan memiliki keinginan menyelesaikan hafalan Alquran 30 juz. Ini menjadi bagian dari cita-cita mereka. yaitu: "Ingin hafal 30 juz" (NF \& NB), "Mau jadi hafidz quran 30 juz" (AN), "Ingin jadi pilot yang hafal Alquran” (MZ), "Jadi penghafal Alquran 30 juz" (ARD).

\section{Target Satu Ayat Panjang dan Dua Ayat Pendek}

Menambah hafalan baru bagi santri penghafal Alquran di Rumah Tadabbur Quran dilakukan dengan menghafal satu sampai dua ayat perhari. Sebagaimana dalam sesi wawancara, mereka rata-rata menyatakan: "Kalau ayatnya panjang-panjang satu, kalau tidak terlalu panjang dua ayat" (NF), "Biasanya dua ayat, kalau panjang satu ayat" (NB), "Satu hari satu sampai tiga ayat" (M), "Kalau panjang dua ayat, kalau pendek empat ayat" (AN), "Seperempat halaman perhari" (ARD).

Dalam menambah hafalan di atas, dilakukan informan dengan membaca secara berulang-ulang atau mendengarkan murattal (MP3 Alquran) secara berulang-ulang.

"Dibaca, terus diulang-ulang sampai hafal" (NF \& MZ)

"Dibaca dulu, kadang dibaca lima kali, kadang juga 10 kali, kadang juga dengar murattal" (AN)

"Caranya diingat-ingat, dibaca ulangulang terus didengar" (M)

"Dibaca sepuluh kali, terus kalau sudah lancar diulang-ulang terus sampai mutqin" (A)

"Dengan cara mendengar murattal" (NB)

"Pake murattal, didengarkan murattal sampai hafal" (BM)

\section{Murāja'ah setelah Subuh dan Magrib}

Murāja'ah atau mengulang hafalan yang sudah dihafal biasa dilakukan informan pada waktu-waktu tertentu. Informan biasa melakukan murāja'ah pada waktu subuh atau setelah salat Subuh dan setelah salat magrib sampai dengan isya. Informan mengatakan bahwa ia murāja'ah: 
"Habis shalat subuh dengan magrib" (NF)

"Habis sholat magrib sampai mau masuk waktu sholat isya" (M)

"Habis sholat subuh sama habis mandi pagi, kalau habis subuh sampai jam 6 sudah dengan murāja'ah, kalau habis mandi biasa murāja'ah sambil nunggu diantar ke sekolah" (ARD)

"Habis sholat magrib sama habis sholat subuh, kalau habis sholat magrib biasanya sampai habis isya, tapi kalau habis sholat subuh sampai mau siap-siap pergi sekolah" (AN)

"Selesai magrib sampai jam sembilan" (MZ)

"Magrib sampai shalat isya, tapi kalau lagi capek, tidak sampai shalat isya, kalau murāja'ah habis shalat subuh, biasanya kalau bangunnya kesiangan dapat satu surah, tapi kalau agak subuh dapat empat surah" (NB)

Hal di atas juga sebagaimana disampaikan oleh orang tua santri:

"Umpamanya kalau bangun pagi habis shalat subuh dia menambah hafalan sambil muraja'ah yang kemarin, habis itu setelah pulang sekolah lagi habis mandi dia muraja'ah lagi hafalannya" (Y)

"Waktu menghafalnya biasanya kalau malam ndak ngantuk berarti malam, tapi kalau malamnya Belva sudah mengantuk biasanya subuh baru menghafal" (EL)

"Kalau dia subuh itu murāja'ah, tapi lihat waktu, terkadang dia itu terlambat bangun kadang ngga murāja'ah, tapi kalau habis magrib itu wajib murāja'ah" (FM)

"Murāja'ah biasa hari sabtu, hari minggu, biasa juga tidak tentu juga waktunya, kapan atau waktu luang murāja'ahmi, tapi biasa itu habis magrib sampai isya sekalian di waktu itu juga untuk nambah hafalannya" (NA)

Selain itu juga, beberapa informan melakukan murāja'ah di sekolah dan di kendaraan (mobil atau motor) dalam suatu perjalanan. Seperti yang dikatakan oleh NF “...biasa di mobil juga kalau pergi ke sekolah".
Hal ini juga sebagaimana disampaikan orang tua NF sebagai berikut:

"Biasanya juga sambung-sambung ayat, tapi itu di luar murāja'ah harian dan hari minggu, kayak di jalan, tapi kalau di mobil ndak, kalau di mobil biasanya dia berjalan surah, jadi misalkan kakaknya an-Naba' nanti adeknya an-Nāzi'at kakaknya lagi 'Abasa adeknya lagi at-Takwīr, jadi berlanjut, itu kalau di mobil wajib itu kalau mau berangkat sekolah toh".

\section{Bermula dari Arahan Orang Tua}

Santri di RTQ Kendari menghafal Alquran sejak dini. Santri mengaku bahwa menghafal Alquran yang dilakukan merupakan perintah dari orang tua. NF, AN, MZ dan NB mengatakan menghafal Alquran "masih disuruh", sedangkan $M$ dan ARD menghafal Alquran atas dasar perintah orang tua dan keinginan sendiri.

Senada dengan hal tersebut di atas, orang tua memerintahkan anaknya untuk menghafal Alquran karena menginginkan anak-anaknya menjadi anak yang șāliḥ dan șālihah. Hal ini sebagaimana diungkapkan Y berikut:

"Ya kembali lagi kepada kewajibannya kita sebagai orang tua mengarahkan utamanya Alquran, setelah kita pertama kali mengajarkan, yang pasti kewajiban pertama mengajarkan, setelah mengajarkan maka dia mau menghafal".

Orang tua yang lain juga berkeinginan untuk bersama-sama dalam kebaikan, seperti yang dikatakan oleh EL:

"Kami ingin bersama-sama di dunia dan akhirat".

Sedangkan orang tua NF dan AN mengatakan:

"Pertama itu arahan dari orang tua, terus mau menghafal sendiri".

Hal yang serupa juga dikatakan oleh NA, bahwa:

"Dari orang tua, tapi saya tidak tau perasaannya dia, awalnya memang orang tua cari-carikan tempat, tapi dari anaknya mauji, nda adaji mau bilang kayak terpaksa begitu..." 


\section{Termotivasi oleh Pahala dan Surga}

Menghafal Alquran bagi santri RTQ Kendari bukan hanya karena mereka diperintahkan oleh orang tua, tetapi juga menjadi keinginan mereka. Hal ini karena santri berkeyakinan bahwa dengan menghafal Alquran bisa memasukkan dirinya ke dalam surga. Alasan ini disampaikan informan NF "Supaya bisa masukkan orang tua ke surga", NB mengatakan "Karena mau memasukkan orang tua ke surga", dan "Bisa dapat pahala", AN juga mengatakan "Mau masuk surga". AN juga menyatakan "Untuk membahagiakan orang tua, dapat pahala". Senada dengan informan AN, informan MZ juga mengatakan "Supaya dapat pahala" dan "Agar masuk surga".

\section{Memiliki Dorongan Memuliakan Orang Tua}

Selain hal yang telah disebutkan di atas, sebagian santri yang lain memiliki keinginan untuk memasukkan ibu dan bapaknya ke dalam surga serta berkeyakinan dapat memberikan hadiah berupa mahkota kemuliaan kepada kedua orang tua jika menghafal Alquran. Hal ini sebagaimana diungkapkan informan:

"Bisa memberikan syafaat kepada orang tua saat di akhirat, bisa memasukkan orang tua ke surga, bisa memberikan mahkota kemuliaan kepada kedua orang tua" (M)

"Supaya bisa masukkan orang tua ke surga" (NF)

"Karena mau memasukkan orang tua ke surga" (NB)

"Karena bisa memasukkan ayah dan bunda di surga dan bisa memakaikan mahkota kemuliaan kepada kedua orang tua" (A)

"Untuk membahagiakan orang tua" (AN)

Keinginan dan keyakinan santri yang bisa memasukkan orang tuanya ke surga serta dapat memberikan mahkota kemuliaan disebabkan oleh nasihat-nasihat serta motivasi yang diberikan orang tua kepada mereka, yaitu:

"...orang tua menginginkan anak yang șalih-ṣalihah, nah menghafal itukan salah satu cara untuk mensolehkan anak" (T)

"...entar kalau kita meninggal semua siapa yang mau doain, siapa yang doain mama sama abi, karena kita ngga ketemu lagi loh, kita sudah di akhirat, kita sudah tidak bisa ketemu lagi, jadi kayak itu...." (FM)

\section{Memiliki Motivasi Mencari Ridho Allah}

Santri menerangkan bahwa menghafal Alquran dilakukan agar dapat memberikan kebahagiaan bukan hanya di dunia tetapi juga di akhirat. Hal ini, karena menurut ARD:

“...menghafal Alquran dengan ketulusan mencari riḍla Allah bisa memasukkan ayah dan bunda di surga dan bisa memakaikan mahkota kemuliaan kepada kedua orang tua".

\section{Terkadang Merasakan Capek, Bosan dan Jenuh}

Rasa capai atau lelah yang dialami oleh sebagian besar santri adalah karena mereka tidak hanya melakukan aktivitas menghafal di RTQ, tetapi juga beraktivitas di sekolah masing-masing.

Perasaan bosan atau jenuh muncul di dalam diri santri penghafal Alquran usia sekolah dasar. Hal ini diungkapkan oleh beberapa santri diantaranya yaitu informan MZ: "Capek, bosan", M juga mengatakan "Kadang kalau lagi capek pulang sekolah, nambahnya waktu magrib". Untuk mengatasi itu biasanya MZ langsung tidur atau membaca buku kesukaannya.

\section{Merasa Kesulitan dengan Panjang Ayat dan Waqaf}

Hal lain yang dirasakan santri penghafal Alquran yaitu perasaan sulit menghafal ayat yang panjang. M mengatakan: "Susah menghafalkan ayat yang panjang”, AN juga mengatakan sulit menghafal ayat yang dirasa panjang: “... kecuali ayat yang panjang”.

Selain ayat yang panjang, santri lebih kesulitan lagi jika ayat yang panjang tersebut juga memiliki banyak tanda waqaf. Sebagaimana informan AN mengatakan: "...baru banyak berhentinya".

Dari hasil wawancara dan observasi, maka dapat dipahami bahwa regulasi diri santri penghafal Alquran pada usia sekolah dasar didasari oleh motivasi transendental atau religius. Ini terlihat dari sebagian besar santri yang termotivasi menghafal karena berharap 
pahala Tuhan. Sehingga santri berusaha menghafal walaupun ayat yang dihafal cukup panjang.

\section{Diskusi}

Berdasarkan uraian hasil penelitian, dapat dipahami bahwa seluruh santri dalam penelitian ini memiliki keinginan untuk menghafal Alquran 30 juz. Hal ini merupakan bentuk penetapan tujuan bagi informan. Penetapan tujuan untuk menyelesaikan hafalan 30 juz merupakan penetapan tujuan jangka panjang (Chairani \& Subandi, 2010). Untuk mencapai tujuan jangka panjang tersebut, para santri membuat strategi-strategi tertentu. Strategi tersebut adalah dengan menetapkan tujuan jangka pendek, yaitu menambah hafalan baru sebanyak 1-2 ayat atau sesuai kemampuan masing-masing. Menurut Chairani dan Subandi (2010) penetapan tujuan ini baik jangka panjang maupun jangka pendek, ditinjau dari aspek kognitif melibatkan proses regulasi diri agar dapat diketahui aktivitas yang dilakukan memberikan manfaat bagi dirinya.

Cara yang digunakan oleh santri dalam penelitian ini, untuk mencapai tujuan jangka pendek dilakukan dengan beragam cara, yaitu menghafal melalui murattal (MP3) Alquran, membaca sampai hafal, membaca 20 kali, atau mendengarkan dan kemudian menirukan bacaan guru (metode kaisa). Metode yang terakhir ini merupakan metode yang diterapkan secara klasikal di RTQ, sedangkan metode lainnya merupakan metode yang digunakan santri secara mandiri untuk menambah hafalan di rumah.

Secara umum cara yang digunakan adalah cara pengulangan. Cara ini menurut Ahsin (dalam Qamariah \& Irsyad, 2016) disebut dengan istilah metode Wahdah atau disebut juga metode Tikrār al-mahfüż (Anwar \& Hafiyana, 2018). Sa'dullah (dalam Chairani \& Subandi, 2010) menjelaskan bahwa aktivitas menghafal merupakan transmisi informasi dari apa yang dilihat dan dibaca ke dalam otak yang harus diupayakan, atau istilah ini juga disebut dengan effortful processing.
Tidak dapat dipungkiri bahwa penetapan tujuan yang ditentukan santri di atas merupakan penetapan yang didasari oleh aspek spiritual. Aspek spiritual yang dipahami oleh santri secara umum diperoleh dari kedua orang tua dan guru. McCullough dan Willoughby (dalam Chairani \& Subandi, 2010) mengemukakan bahwa aspek spiritual memiliki peran yang cukup penting. Nilai-nilai agama yang dipahami dan terinternalisasi ke dalam diri seseorang akan memengaruhinya dalam memilih, mengatur tujuan serta mencapainya.

Dalam upaya pencapaian tujuan, pengaturan waktu juga menjadi hal yang tidak dapat diabaikan atau sangat penting (Ubaid, 2019). Penghafal Alquran harus mengatur dan memanfaatkan waktu-waktu terbaiknya untuk menghafal Alquran (Ubaid, 2019). Santri dalam penelitian ini menghafal Alquran pada waktu subuh atau setelah șalāt subuh, dan setelah șalāt magrib sampai isya. Waktu-waktu ini menurut Roful dan Ridhoul (dalam Wahyudi \& Wahidi, 2017) merupakan diantara waktu-waktu terbaik untuk menghafal.

Sementara itu, dalam pemeliharaan tujuan, hal yang menjadi kewajiban bagi penghafal Alquran adalah melakukan murāja'ah atau mengulang-ulang hafalan yang telah dihafal sebelumnya. Seorang penghafal Alquran tidak dibenarkan untuk menambah hafalan baru jika hafalan sebelumnya belum dikuasai dengan baik (Chairani \& Subandi, 2010). Rasa ingin cepat menyelesaikan hafalan merupakan salah satu hambatan dalam proses menghafal (Chairani \& Subandi, 2010).

Peran orang tua dalam proses menghafal anak sangat penting (Susianti, 2016). Santri dalam penelitian ini secara keseluruhan pada mulanya menghafal Alquran atas inisiatif orang tua. Keinginan orang tua menjadikan anaknya menjadi penghafal Alquran didasari oleh informasi yang didapatkan serta dipahami, bahwa penghafal Alquran memiliki keutamaankeutamaan tertentu. Keutamaan bagi penghafal Alquran seperti akan dimasukkan ke dalam surga bersama para rasul yang mulia, dapat memberikan pertolongan kepada kedua orang tua serta memberikan mahkota kemuliaan 
kepadanya, atau mendapat kedudukan yang khusus di sisi Allah Swt. (Anwar \& Hafiyana, 2018). Orang tua santri dalam hal ini berupaya memotivasi anak-anaknya untuk menghafal Alquran.

Sebagaimana penjelasan sebelumnya, bahwa santri dalam penelitian ini menghafal Alquran atas dorongan atau perintah dari orang tua. Seseorang yang melakukan suatu aktivitas atas arahan dan dorongan orang lain disebut dengan motivasi introjeksi (Chairani \& Subandi, 2010). Menurut Budi dkk. (dalam Sulaeman dkk., 2017) ini merupakan tahapan seseorang melakukan tugasnya untuk menghindari rasa bersalah jika tidak melakukan atau menyelesaikan tugasnya. Beberapa santri yang masih memiliki motivasi ini sangat tergantung pada bantuan dari orang tua, terutama dalam menghadapi hambatanhambatan. Hal senada juga dikemukakan oleh Chairani dan Subandi (2010) bahwa santri dengan motivasi introjeksi akan sangat bergantung kepada orang tua. Bahkan hal ini akan menimbulkan rasa cemas, merasa bersalah serta konsekuensi negatif jika tidak melakukan arahan orang tua.

Pada santri yang mampu dan memiliki motivasi intrinsik dalam menghafal Alquran merasa bahwa kegiatan yang dilakukan memberi suatu hal yang bermanfaat bagi dirinya. Menurut Chairani dan Subandi (2010) seseorang yang memiliki motivasi intrinsik dapat digambarkan sebagai seseorang yang memiliki kesungguhan, keuletan, ketekunan serta vitalitas. Chairani dan Subandi (2010) menambahkan bahwa motivasi dalam diri seseorang, dapat mengalami perkembangan atau perubahan yang salah satunya dipengaruhi oleh pengetahuan atau informasi yang relevan dengan tujuan yang hendak dicapai.

Santri dalam penelitian ini sebagian besar sedang mengalami masa transisi atau peralihan dari motivasi introjeksi menuju motivasi intrinsik. Hal ini dapat dilihat dari ketekunan mereka melakukan murāja'ah hafalan baik dengan pengawasan orang tua atau tanpa pengawasan. Namun, di sisi lain, mereka terkadang memperlihatkan ketidakmampuan untuk menyelesaikan hambatan yang dihadapi khususnya rasa lelah atau bosan. Suasana hati seperti rasa lelah dan bosan juga dapat memengaruhi kemampuan seseorang dalam meregulasi dirinya untuk menghafal (Chairani \& Subandi, 2010).

Dalam menyikapi suasana hati seperti hal di atas, beberapa santri melakukan aktivitas yang menurutnya dapat mengurangi perasaan negatif tersebut, yaitu dengan membaca buku, atau beristirahat (tidur). Aktivitas tersebut dianggap dapat memberikan ketenangan bagi dirinya. Aktivitas lain yang dapat mendatangkan ketenteraman yaitu puasa (Muhopilah dkk., 2018). Akan tetapi, hal ini belum dilakukan secara maksimal oleh santri. Selain itu, dalam proses menghafal, mereka juga merasa kesulitan ketika menghafal ayatayat yang panjang serta memiliki banyak tempat berhenti. Hanya saja, santri dalam penelitian ini belum dapat memahami serta memaknai kesulitan atau hambatan yang dialami sebagai suatu ujian atau cobaan yang diberikan Allah Swt. kepada dirinya. Artinya, santri belum mampu mengatur aspek afeksi dalam diri. Menurut Chairani dan Subandi (2010) ada beberapa sifat yang perlu dilakukan atau dikembangkan bagi santri penghafal Alquran, yaitu sabar, berupaya sungguhsungguh, ulet, tidak mudah putus asa, optimis, berpikir positif, tidak sombong serta bertawakkal dengan selalu berdoa kepada Allah Swt.

Dari hasil temuan dan pembahasan di atas, dapat dipahami bahwa regulasi diri sangat penting bagi penghafal Alquran pada usia sekolah dasar. Regulasi diri penghafal Alquran pada usia sekolah dasar masih membutuhkan bimbingan dan arahan sehingga dapat lebih optimal.

\section{Simpulan}

Regulasi diri santri penghafal Alquran usia sekolah dasar sebagian besar masih dibimbing oleh orang tua baik dalam penetapan tujuan, motivasi dan aspek afeksi. Akan tetapi bimbingan tersebut mengalami internalisasi ke 
dalam diri penghafal Alquran sesuai dengan pengetahuan serta pemahaman mereka tentang keutamaan penghafal Alquran. Dalam hal pencapaian dan penetapan tujuan dipengaruhi aspek motivasional yang didominasi oleh motivasi transendental. Sedangkan pada aspek afeksi, sebagian penghafal Alquran mampu mengelola setiap perasaan yang muncul sehingga dapat membantunya dalam mengatur keseimbangan emosi agar tujuan dapat dicapai. Namun, di sisi lain terdapat aspek-aspek afeksi yang masih membutuhkan bantuan orang tua. Hal ini merupakan bagian dari introjection atau proses peralihan motivasi ekstrinsik menuju motivasi intrinsik. Ketiga aspek dalam regulasi diri tidak dapat dipisahkan, ketiganya harus bersinergi sehingga menghasilkan regulasi diri yang lebih baik.

\section{Referensi}

Adipura, K., Yuniarrahmah, E., \& Akbar, S. N. (2013). Perbedaan regulasi diri dalam belajar pada siswa kelas akselerasi dan siswa kelas reguler di Banjarmasin. Jurnal Ecopsy, 1(3), 3-5. http://dx.doi.org/10.20527/ecopsy.v1i3.497

Akbar, A., \& Ismail, H. (2016). Metode tahfidz al-qur'an di pondok pesantren kabupaten Kampar. Jurnal Ushuluddin, 24(1), 91102.

http://dx.doi.org/10.24014/jush.v24i1.1517

al Maududi, A. A., Mujahidin, E., \& Hafidhuddin, D. (2014). Metode tahfizh alqur'an bagi pelajar dan mahasiswa. Ta'dibuna Jurnal Pendidikan Islam, 3(1), $1-15$.

http://dx.doi.org/10.32832/tadibuna.v3i1.5 68

Anindyta, P., \& Suwarjo. (2014). Pengaruh problem based learning terhadap keterampilan berpikir kritis dan regulasi diri siswa kelas V. Jurnal Prima Edukasia, 2(2), 209-222. https://doi.org/10.21831/jpe.v2i2.2720

Anwar, K., \& Hafiyana, M. (2018). Implementasi metode ODOA (one day one ayat) dalam meningkatkan kemampuan menghafal al-Qur'an. Jurnal Pendidikan Islam Indonesia, 2(2), 181-198. https://doi.org/10.35316/jpii.v2i2.71

Atabik, A. (2014). The living qur'an: Potret budaya tahfiz al-qur'an di nusantara. Jurnal Penelitian, 8(1), 161-178. http://doi.org/10.21043/jupe.v8i1.1346

Boeree, C. G. (2010). Personality theories: Melacak kepribadian anda bersama psikolog dunia (Edisi Baru). Ar-Ruzz Media.

Buckner, J. C., Mezzacappa, E., \& Beardslee, W. R. (2009). Self-regulation and its relations to adaptive functioning in low income self-regulation and its relations to adaptive functioning in low income youths. American Journal of Orthopsychiatry, 79(1), $\quad$ 19-30. https://doi.org/10.1037/a0014796

Chairani, L., \& Subandi, M. A. (2010). Psikologi santri penghafal al-Qur'an; Peranan regulasi diri. Pustaka Pelajar.

Colman, R. A., Hardy, S. A., Albert, M., Raffaelli, M., \& Crockett, L. J. (2006). Early predictors of self-regulation in middle childhood early predictors of selfregulation in middle childhood. Faculty Publications, Department of Psychology, 421-437. https://doi.org/10.1002/icd.469

Fauziyah, A., Ulfiah, \& Hidayat, I. N. (2018). Efektivitas metode tamyiz terhadap memori dalam mempelajari alquran pada santri pondok pesantren quran. JPIB : Jurnal Psikologi Islam dan Budaya, 1(1), $37-52$. https://doi.org/10.15575/jpib.vlil.2070

Ghufron, M. N., \& Risnawita, R. (2010). Teoriteori psikologi. Ar-Ruzz Media.

Herawaty, Y., \& Wulan, R. (2013). Hubungan antara keberfungsian keluarga dan daya juang dengan belajar berdasar regulasi diri pada remaja. Jurnal Psikologi, 9(1997), 138-147. http://dx.doi.org/10.24014/jp.v9i2.176

Husna, A. N., Hidayati, F. N., \& Ariati, J. (2014). Regulasi diri mahasiswa berprestasi. Jurnal Psikologi Undip, 13(1), 50-63. 
https://doi.org/10.14710/jpu.13.1.50-63

Marza, S. E. (2017). Regulasi diri remaja penghafal al-qur'an di pondok pesantren al-qur'an jami'atul qurro' Sumatera Selatan. Intelektualita, 06(1), 145-160. https://dx.doi.org/10.19109/intelektualita.v $6 \mathrm{i} 1.1306$

Miksza, P. (2012). The development of a measure of self-regulation practice behavior for begining and intermediate instrumental music students. Journal of Research in Music Education, 59(4), 321338.

https://doi.org/10.1177/002242941141471 7

Minauli, I., \& Butarbutar, I. (2011). Hubungan antara efikasi diri dan regulasi diri dalam belajar prestasi akademik mahasiswa. Jurnal Analitika, 3(2), 79-84. https://doi.org/10.31289/analitika.v3i2.748

Mu'min, S. A. (2016). Regulasi diri dalam belajar mahasiswa yang bekerja. Jurnal AlTa'dib, 9(1), 1-20. http://dx.doi.org/10.31332/atdb.v9i1.499

Muhopilah, P., Gamayanti, W., \& Kurniadewi, E. (2018). Hubungan Kualitas puasa dan kebahagiaan santri pondok pesantren AlIhsan. JPIB : Jurnal Psikologi Islam dan Budaya, 1(1), 53-66. http://dx.doi.org/10.15575/jpib.v1i1.2071

Munawwir, A. W. (1997). Kamus al-munawwir arab-indonesia terlengkap (Edisi kedua). Pustaka Progressif.

Prastowo, A. (2019). Metode penelitian kualitatif dalam perspektif rancangan penelitian (Cet. II). Ar-Ruzz Media.

Qamariah, N., \& Irsyad, M. (2016). Metode cepat \& mudah agar anak hafal al-qur'an. Semesta Hikmah.

Rachmah, D. N. (2015). Regulasi diri dalam belajar pada mahasiswa yang memiliki peran banyak. Jurnal Psikologi, 42(1), 6177. https://doi.org/10.22146/jpsi.6943

Raco, J. R. (2010). Metode penelitian kualitatif; jenis, karakteristik dan keunggulannya. PT Grasindo.

Rifa'i, A. (2018). Pendidikan tahfiz anak usia dini (Taud). Al Qalam: Jurnal Ilmiah
Keagamaan dan Kemasyarakatan, 11(23), 113. https://doi.org/10.35931/aq.v0i0.6

Ruminta, Tiatri, S., \& Mularsih, H. (2017). Perbedaan regulasi diri belajar pada siswa sekolah dasar kelas VI ditinjau dari jenis kelamin. Jurnal Muara Ilmu Sosial, Humaniora, dan Seni, 1(2), 286-294. http://dx.doi.org/10.24912/jmishumsen.v1i 2.1463

Sugiyono. (2012). Metode penelitian pendidikan: kuantitatif, kualitatif, dan $R \&$ $D$. Alfabeta.

Sulaeman, B., Sahrani, R., \& Monika, S. (2017). Intervensi self-regulation empowerment program untuk meningkatkan motivasi berprestasi mahasiswa non reguler di jurusan $\mathrm{X}$ universitas X. Jurnal Muara Ilmu Sosial, Humaniora, dan Seni, 1(2), 519-528. https://doi.org/10.24912/jmishumsen.v1i2. 1468

Sulistyaningsih, Y. F. E., \& Cahyani, B. H. (2011). Peran reinforcement dalam kemampuan regulasi diri siswa SD selama di kelas. Jurnal Spirit, 2(1), 1-13.

Susanti, R. (2015). Efektifitas Konseling realitas untuk peningkatan regulasi diri mahasiswa dalam menyelesaikan skripsi. Jurnal Psikologi, 11(2), 88-93.

Susianti, C. (2016). Efektivitas metode talaqqi dalam meningkatkan kemampuan menghafal al-qur'an anak usia dini. Tunas Siliwangi, $2(1), \quad 1-19$. https://doi.org/10.22460/ts.v2i1p1-19.305

Lukmawati, Tanjung, F., \& Supriyanto, J. (2017). Al-qur'an itu menjaga diri: Peranan regulasi diri penghafal al-qur'an. Psikis-Jurnal Pskologi Islami, 3(2), 94105.

https://doi.org/10.19109/psikis.v3i3.1754

Ubaid, M. (2019). 9 langkah mudah menghafal al-qur'an. Aqwam.

Winata, H., \& Friskilia S, O. (2018). Hasil belajar siswa Sekolah Menengah Kejuruan (Self regulated as predictors of student achievement at vocational high school). Jurnal Pendidikan Manajemen Perkantoran, 1(2), 37-44. 
Zimmerman, B. J. (1989). A social cognitive view of self-regulated academic learning. Journal of Educational Psychology, 81(3), 329-339. https://doi.org/10.1037/00220663.81.3.329 